\title{
PENINGKATAN KEMAMPUAN BERPIKIR KRITIS DAN PRESTASI BELAJAR SISWA MELALUI PENGGUNAAN MODEL PEMBELAJARAN PROBLEM SOLVING DILENGKAPI DENGAN SMART CARD PADA MATERI KELARUTAN DAN HASIL KALI KELARUTAN PADA KELASXI IPA DI SMA ISLAM 1 SURAKARTA TAHUN AJARAN 2016/2017
}

\author{
Dyah Kurniastuti, Widiastuti Agustina E.S*, dan Budi Utami \\ Program Studi Pendidikan Kimia, FKIP,Universitas Sebelas Maret, Surakarta, Indonesia \\ *Keperluan Korespondensi, telp: +6281280660500, email: widiastuti_aes@staff.uns.ac.id
}

\begin{abstract}
ABSTRAK
Penelitian ini bertujuan untuk meningkatkan kemampuan berpikir kritis dan prestasi belajar siswa kelas XI IPA SMA Islam 1 Surakarta tahun pelajaran 2016/2017 melalui penerapan model pembelajaran Problem Solving dilengkapi dengan Smart Card pada materi kelarutan dan hasil kali kelarutan. Penelitan yang dilakukanmerupakan penelitian tindakan kelas dan terdiri dari dua siklus.Setiap siklusnya terdapat empat tahap yaitu, perencanaan tindakan, pelaksanaan tindakan, observasi dan evaluasi serta refleksi.Subjek penelitiannya adalah kelas XI IPA SMA Islam 1 Surakarta tahun pelajaran 2016/2017.Penelitian ini menggunakan teknik analisis data dan deskriptif.Data pada penelitian diperoleh melalui observasi, wawancara, kajian dokumen, angket dan tes. Hasil penelitian menunjukkan bahwa kemampuan berpikir kritis siswa dengan kategori tinggi dan sangat tinggi sebesar $15 \%$ pada pra siklus menjadi $90 \%$ pada siklus I, prestasi belajar siswa aspek kognitif dengan ketuntasan siswa sebesar $45 \%$ pada siklus I dan $75 \%$ pada siklus II, sedangkan ketercapaian prestasi belajar aspek afektif pada siklus I dan siklus II sebesar $100 \%$. Kesimpulan dari penelitian ini adalah model pembelajaran problem solving dilengkapi smart card dapat meningkatkan kemampuan berpikir kritis dan prestasi belajar siswa pada materi kelarutan dan hasil kali kelarutan kelas XI IPA SMA Islam 1 Surakarta Tahun Pelajaran 2016/2017.
\end{abstract}

Kata kunci : Problem Solving, Smart Card, Kemampuan Berpikir Kritis, Prestasi Belajar, Kelarutan dan Hasil Kali Kelarutan.

PENDAHULUAN.

Pembelajaran kimia merupakan suatu proses pembelajaran yang memerlukan penalaran dan pemahaman konsep yang tinggi. Oleh karena itu, perlu peran guru untuk membantu siswa memahami konsep pada materi kimia, sehinggakualitas guru juga perlu ditingkatkan karena guru merupakan komponen paling menentukan dalam sistem pendidikan secara keseluruhan, yang harus mendapat perhatian sentral, pertama dan utama [1].
Pembelajaran kimia sesuai kurikulum tingkat satuan pendidikan menekankan pada peran guru sebagai fasilitator bagi siswa dan menciptakan pembelajaran aktif, inovatif, kreatif, efektif dan menyenangkan (PAIKEM).

Pada kenyataannya, pembelajaran kimia yang dilakukan di SMA Islam 1 Surakarta masih cenderung teacher centre dan media pembelajaran masih belum inovatif, sehingga siswa tidak aktif dalam proses pembelajaran. Guru belum memanfaatkan secara maksimal fasilitas sekolah yang telah disediakan seperti proyektor dan laboratorium kimia, 
sehingga potensi peserta didik dan kemampuan berpikir kritis mereka tidak berkembang meskipun siswa memiliki motivasi yang tinggi pada pelajaran kimia.

Kemampuan berpikir kritis siswa SMA Islam 1 Surakarta masih rendah terbukti dari hasil tes berpikir kritis yang menunjukkan bahwa 55\% siswa memiliki kemampuan berpikir kritis rendah, 30\% siswa memiliki kemampuan berpikir kritis sedang dan $15 \%$ siswa siswa memiliki kemampuan berpikir kritis tinggi. Jika nilai keterampilan kognitif dan berpikir kritis siswa rendah maka prestasi belajar siswa juga akan rendah [2].

Nilai ketuntasan aspek kognitif siswa pada materi kelarutan dan hasil kali kelarutan tahun pelajaran 2014/2015 sebesar $30,43 \%$ sedangkan pada tahun pelajaran 2015/2016 sebesar 27,27\%. Dari hasil tes kemampuan berpikir kritis yang telah dilakukan diduga pada tahun pelajaran 2016/2017 nilai aspek kognitif materi kelarutan dan hasil kali kelarutan siswa juga akan rendah.

Materi kelarutan dan hasil kali kelarutan merupakan materi yang membutuhkan pemahaman konsep yang baik, untuk itu model pembelajaran yang digunakan harus sesuai dan sangat tidak tepat jika menggunakan model ceramah saja.Oleh karena itu, perlu digunakan model yang melibatkan siswa dalam menyelesaikan masalah, melatih siswa untuk mengembangkan kemampuan berpikir secara kritis dan logis.

Salah satu upaya untuk meningkatkan kemampuan berpikir kritis dan prestasi belajar siswa XI IPA SMA Islam 1 Surakarta digunakan model pembelajaran Problem Solving.Problem solving bukan hanya sekedar model mengajar tetapi juga merupakan suatu model berpikir karena dalam problem solving dapat menggunakan modelmodel lainnya yang dimulai dengan mencari data sampai pada menarik kesimpulan [3]. Selain itu, model pembelajaran problem solving atau pemecahan masalah ini banyak menumbuhkan aktivitas belajar secara individual maupun kelompok [4]. Sintaks problem solving terdiri dari 5 tahap berikut, (1) Guru membagikan lembar diskusi berupa pemecahan masalah kepada siswa (2) Siswa mengidentifikasi masalah (3) Siswa mencari alternatif penyelesaian permasalahan (4) Siswa melakukan evaluasi terhadap hasil penyelesaian permasalahan (5) Siswa mempresentasikan hasil penyelesaian permasalahan kemudian menarik kesimpulan [5].

Penggunaan model problem solving dimaksudkan untuk melatih siswa dalam meningkatkan kemampuan berpikir mereka secara kritis sehingga prestasi belajar siswa juga akan meningkat. Model problem solving ini belum pernah digunakan siswa SMA Islam 1 Surakarta sehingga agar siswa lebih tertarik maka dilengkapi dengan media pembelajaran. Media pembelajaran yang dianggap sesuai adalah smart card. Media kartu dianggap sangat cocok karena media kartu menimbulkan motivasi yang samabagi siswa serta dapat mendorong mereka untuk mempelajari konsep-konsep tertentu [6]. Media smart card dalam penelitian ini berisi ringkasan materi dan kumpulan rumus untuk melengkapi referensi siswa dalam melaksanakan model pembelajaran problem solving.

Penerapan model pembelajaran problem solving dilengkapi dengan smart card diprediksi dapat meningkatkan kemampuan berpikir kritis dan prestasi belajar siswa.Hal ini didukung dengan hasil penelitian model pembelajaran problem solving dapat meningkatan kemampuan berpikir kritis dan prestasi belajar siswa pada materi kelarutan dan hasil kali kelarutan [7].

\section{METODE PENELITIAN}

Penelitian yang dilakukan merupakan penelitian tindakan kelas (PTK). Dalam melaksanakan penelitian tindakan kelas dibutuhkan empat tahapan yaitu 1) perencanaan (planning), 2) tindakan (acting), 3) pengamatan (observing), 4) refleksi (reflecting), dari rangkaian tahapan tersebut akan terbentuk menjadi sebuah siklus [8]. Subjek pada penelitian ini adalah siswa kelas XI IPA semester genap SMA Islam 1 Surakarta tahun pelajaran 2016/2017 dengan jumlah 20 siswa yang terdiri dari 6 siswa laki-laki dan 
14 siswa perempuan.Kondisi siswa di kelas XI IPA tidak terlalu aktif, hanya beberapa siswa saja yang selalu aktif menjawab pertanyaan yang diberikan oleh guru, sehingga prestasi belajar siswa tidak merata.

Teknik pengumpulan data yang digunakan dalam penelitian ini meliputi tes, observasi, wawancara, kajian dokumen dan angket.Analisis data dilakukan menggunakan teknik kualitatif dan kuantitatif. Teknik analisis kualitatif dilakukan dalam tiga komponen yaitu, reduksi data, penyajian data dan penarikan kesimpulan dan verifikasi [9].

Uji validitas data menggunakan teknik triangulasi.Triangulasi dilakukan berdasarkan tiga sudut pandang, yaitu sudut pandang guru, sudut pandang siswa dan sudut pandang observer [10]. Triangulasi digunakan untuk mengumpulkan data sekaligus menguji kredibilitas data dengan teknik pengumpulan data dari berbagai sumber data[11] .

\section{HASIL DAN PEMBAHASAN}

Pada awal tindakan dilakukan tahap wawancara, kajian dokumentasi dan angket untuk mengetahui kondisi awal siswa.Data hasil wawancara dengan guru menunjukkan bahwa siswa kelas XI IPA SMA Islam 1 Surakarta memiliki motivasi belajar tinggi namun kemampuan berpikir kritis dan matematisnya rendah. Hasil kajian dokumentasi diperoleh bahwa ketuntasan nilai siswa pada materi kelarutan dan hasil kali kelarutan selama 2 tahun berturut-turut masih rendah. Sedangkan dari hasil tes prasiklus kemampuan berpikir kritis diperoleh hasil bahwa 15\% siswa kelas XI IPA SMA Islam 1 Surakarta mempunyai kemampuan berpikir kritis yang tinggi. Sehingga perlu dilakukan tindakan untuk menangani permasalah tersebut dengan menggunakan model pembelajaran problem solving dilengkapi smart card.

\section{Siklus I}

\section{a. Perencanaan Tindakan}

Pada tahap perencanaan, peneliti dan guru melakukan kajian terhadap silabus mata pelajaran kimia.Silabus berasal dari guru dan dikembangakan oleh peneliti. Berdasarkan silabus ini peneliti membuat rencana pelaksanaan pembelajaran (RPP). Selanjutnya adalah penyusunan instrumen kemampuan berpikir kritis, aspek kognitif dan aspek afektif.

Pada siklus I terdiri dari 4 pertemuan, setiap pertemuan menggunakan model pembelajaran problem solving dilengkapi dengan smart card.Smart card digunakan sebagai penunjang kegiatan pembelajaran dan menambah referensi bagi siswa pada materi kelarutan dan hasil kali kelarutan.

\section{b. Pelaksanaan Tindakan}

Pelaksanaan tindakan pada siklus I berupa serangkaian kegiatan pembelajaran di kelas XI IPA SMA Islam 1 Surakarta menggunakan model pembelajaran problem solving yang berlangsung sesuai sintaks dalam rencana pelaksanaan pembelajaran. Siklus I terdiri dari 3 kali pertemuan penyampaian materi dan 1 kali pertemuan untuk kegiatan evaluasi, kegiatan evaluasi berupa pemberian soal tes kognitif, angket afektif dan tes kemampuan berpikir kritis. Alokasi waktu tiap pertemuan adalah $2 \times 45$ menit. Materi yang dibahas dalam setiap pertemuan terdiri dari kelarutan (s), tetapan hasil kali kelarutan (Ksp), hubungan kelarutan dan hasil kali kelarutan, pengaruh ion senama terhadap kelarutan, pengaruh $\mathrm{pH}$ terhadap kelarutan dan hubungan Qc dengan Ksp.

Pada pertemuan pertama diawali dengan mengkondisikan kelas, absensi siswa, memberikan apersepsi, orientasi dan motivasi. Penyampaian materi pada kegiatan awal hanya berisi penjelasan singkat mengenai konsep materi Ksp. Selanjutnya kegiatan inti dilakukan sesuai dengan sintaks model pembelajaran problem solving dimana guru membentuk membagi siswa menjadi 5 kelompok yang dibagi secara heterogen. Kemudian guru memberikan permasalahan kepada siswa berupa soalsoal dan membantu siswa dengan menyediakan media berupa smart card yang diharapkan dapat memudahkan siswa untuk memecahkan permasalahan yang telah diberikan oleh guru. Setelah siswa berdiskusi mengenai solusi 
pemecahan masalah dan telah dievaluasi dalam satu kelompok kemudian perwakilan kelompok mempresentasikan hasil diskusi yang telah diperoleh. Guru memberikan umpan balik kepada siswa mengenai hasil diskusi mereka dan menjelaskan beberapa hal yang belum dipahami oleh siswa. Pada kegiatan akhir, guru memberikan kesimpulan dari hasil pembelajaran yang dilakukan.Untuk mengetahui kemampuan siswa secara individu maka dilakukan posttest yang terdiri dari beberapa soal dan telah mencakup materi pada pertemuan pertama.

Pada pertemuan pertama, masih banyak siswa yang sulit melaksanakan model pembelajaran problem solving dikarenakan model pembelajaran ini baru pertama kali dilaksanakan di kelas XI IPA SMA Islam 1 Surakarta, sehingga banyak siswa yang belum aktif dalam menjawab pertanyaan yang diberikan oleh guru. Namun, untuk media pembelajaran berupa smart card sudah dimanfaatkan siswa dengan baik untuk menyelesaikan permasalahan berupa soal yang diberikan oleh guru.

Pada pertemuan kedua dan ketiga proses pembelajaran sama dengan pertemuan pertama. Pada pertemuan kedua dan ketiga ini siswa mulai aktif bertanya, menjawab pertanyaan, berdiskusi dengan teman dan mempresentasikan hasil diskusi dengan percaya diri.Nilai diskusi siswa juga sudah meningkat dibandingkan dengan pertemuan pertama.

\section{c. Observasi Tindakan}

Hasil observasi selama proses pembelajaran berlangsung menunjukkan bahwa terdapat peningkatan keaktifan siswa pada setiap pertemuan meskipun belum seluruh siswa yang aktif dalam pembelajaran. Terdapat 2-3 siswa yang melamun dan mengobrol dengan teman namun paling banyak terdapat pada pertemuan pertama karena siswa masih proses adaptasi dengan model pembelajaran yang diberikan. Pada kegiatan diskusi masih banyak siswa yang tidak ikut aktif dalam mengerjakan tugas yang diberikan oleh guru.Ketika pembelajaran berlangsung, lebih dari 10 siswa aktif menjawab pertanyaan spontan yang diberikan oleh guru meskipun belum ditunjuk dan rasa ingin tahu mereka tinggi sehingga banyak yang bertanya ketika ada hal yang masih membingungkan.Meskipun begitu pembelajaran pada siklus I masih perlu meningkatkan keaktifan siswa secara merata.

Penilaian kemampuan berpikir kritis dilakukan pada akhir siklus. Menurut Ennis terdapat 12 indikator kemampuan berpikir kritis, namun pada penelitian ini hanya digunakan 8 indikator, yaitu (1) Mengidentifikasi asumsi (2) Mendeduksi dan mempertimbangkan hasil deduksi (3) Menginduksi dan mempertimbangkan hasil induksi (4) Membuat generalisasi (5) Membuat dan menentukan nilai pertimbangan (6) Mengamati dan mempertimbangkan suatu laporan hasil observasi (7) Menentukan tindakan (8) Menganalisis pertanyaan [12].Tes kemampuan berpikir kritis berupa soal objektif yang berjumlah 10 soal dimana penilaiannya adalah benar dan salah yang dikategorikan menjadi 5 kategori pengelompokan yaitu sangat tinggi (ST), tinggi $(T)$, sedang $(S)$, rendah $(R)$ dan sangat rendah (SR) [13].

Hasil penilaian terhadap kemampuan berpikir kritis siswa pada siklus I dinyatakan dalam Tabel 1.

Tabel 1. Hasil Penilaian Kemampuan Berpikir Kritis Siklus I

\begin{tabular}{cccccc}
\hline \multirow{2}{*}{ Aspek } & \multicolumn{5}{c}{ Jumlah Siswa (Orang) } \\
\cline { 2 - 6 } & ST & T & S & R & SR \\
\hline Kemampuan & 14 & 4 & 2 & - & - \\
Berpikir Kritis & & & & \\
\hline
\end{tabular}

Hasil tes aspek kognitif pada siklus I dapat dilihat pada Tabel 2.

Tabel 2. Hasil Tes Aspek Kognitif Siklus I

\begin{tabular}{ccc}
\hline \multirow{2}{*}{ Aspek } & \multicolumn{2}{c}{ Jumlah siswa } \\
\cline { 2 - 3 } & Tuntas & $\begin{array}{c}\text { Belum } \\
\text { Tuntas }\end{array}$ \\
\hline Kognitif & 9 & 11 \\
\hline
\end{tabular}

Hasil analisis aspek kognitif menunjukkan bahwa hanya 9 siswa atau $45 \%$ siswa yang mencapai ketuntasan 
dan 11 siswa atau 55\% siswa belum mencapai ketuntasan. Pada penilaian kognitif ini, terdapat 6 indikator yang harus dicapai siswa namun hanya 3 indikator yang melebihi target ketuntasan yaitu $70 \%$.

Hasil kemampuan berpikir kritis dan kognitif siswa tidak berbanding lurus pada siklus I dikarenakan ada beberapa faktor selain kemampuan berpikir kritis yang mempengaruhi nilai kognitif siswa pada materi kelarutan dan hasil kali kelarutan. Faktor tersebut diantaranya adalah kemampuan matematis dan kemampuan memori yang dalam penelitian ini tidak dijadikan sebagai variable proses.

Penilaian siswa pada aspek afektif terbagi menjadi 4 kategori yaitu sangat baik (SB), baik (B), kurang baik (KB) dan tidak baik (TB). Hasil penilaian aspek afektif siklus I dapat dilihat pada Tabel 3. berikut.

Tabel 3. Hasil Penilaian Aspek Afektif Siklus I

\begin{tabular}{ccccc}
\hline \multirow{2}{*}{ Aspek } & \multicolumn{5}{c}{ Jumlah Siswa } \\
\cline { 2 - 5 } & SB & B & KB & TB \\
\hline Afektif & 13 & 7 & 0 & 0 \\
\hline
\end{tabular}

Hasil analisis prestasi belajar aspek afektif yang dilakukan pada 20 siswa kelas XI IPA SMA Islam 1 Surakarta, terdapat $65 \%$ siswa yang masuk dalam kategori sangat baik dan $35 \%$ siswa yang masuk dalam kategori baik.

\section{d. Refleksi Tindakan}

Hasil analisis siklus I menunjukkan bahwa aspek kognitif belum mencapai target sebesar $70 \%$ Terdapat 3 indikator aspek kognitif yang belum mencapai target sehingga perlu dilakukan tindakan siklus II. Tindakan yang dilakukan berfokus pada pemberian soal-soal diskusi tentang pendalaman konsep dan kemampuan matematis siswa.Selain itu, dilakukan juga pemberian motivasi yang lebih kepada siswa dan melakukan pembelajaran yang lebih menyenangkan namun tetap serius.

\section{Siklus II}

\section{a. Perencanaan Tindakan}

Pelaksanaan pembelajaran pada siklus II hanya difokuskan pada materi dengan indikator-indikator yang belum tuntas pada siklus I yaitu 1) Menjelaskan pengertian kelarutan dan hasil kali kelarutan, 2) Menjelaskan pengaruh $\mathrm{pH}$ terhadap kelarutan, 3) Memperkirakan terbentuknya endapan berdasarkan kelarutan.Selain berfokus pada kemampuan pemahaman materi oleh siswa, guru juga mendorong siswa untuk lebih aktif lagi dalam proses pembelajaran. Untuk meningkatkan keaktifan siswa, guru menunjuk siswa yang masih belum aktif untuk mewakili kelompoknya dalam presentasi sehingga siswa menjadi lebih aktif.

\section{b. Pelaksanaan Tindakan}

Pertemuan pertama siklus II dilaksanakan pada 25 April 2017, materi yang disampaikan mengenai kelarutan dan hasil kali kelarutan, pengaruh $\mathrm{pH}$ terhadap kelarutan dan reaksi pengendapan.Siklus II menunjukkan bahwa banyak siswa yang lebih aktif dan bersemangat dalam menyelesaikan permasalahan yang diberikan oleh guru. Siswa yang sebelumnya tidak aktif dalam proses pembelajaran ditunjuk oleh guru untuk mempresentasikan hasil diskusi juga sudah menyampaikannya secara percaya diri.

\section{c. Observasi Tindakan}

Hasil observasi menunjukkan bahwa keaktifan siswa meningkat baik secara individu maupun kelompok. Tidak terdapat siswa yang mengobrol sendiri ketika diskusi meskipun ada beberapa siswa yang masih mengobrol sendiri ketika guru menjelaskan dan terdapat 1 siswa yang masih melamun ketika guru memberikan penjelasan mengenai pembelajaran.Pada siklus II hanya dilakukan evaluasi berupa tes aspek kognitif.

Hasil analisis aspek kognitif siklus II dapat dilihat pada Tabel 4. 
Tabel 4. Hasil Tes Aspek Kognitif Siklus

\begin{tabular}{ccc} 
II & \multicolumn{2}{c}{ Jumlah siswa } \\
\cline { 2 - 3 } & Tuntas & $\begin{array}{c}\text { Belum } \\
\text { Tuntas }\end{array}$ \\
\hline Kognitif & 15 & 5 \\
\hline
\end{tabular}

Hasil analisa aspek kognitif pada siklus II diperoleh bahwa sebanyak 15 siswa atau $75 \%$ telah mencapai ketuntasan KKM sebesar 72 sedangkan 5 siswa atau 25\% belum mencapai ketuntasan KKM. Apabila dilihat dari ketuntasan tiap indikator menunjukkan bahwa semua indikator mengalami peningakatan pada siklus II.Target ketuntasan tiap indikator aspek kognitif sebesar $70 \%$.

\section{d. Refleksi Tindakan}

Hasil analisis siklus II menunjukkan bahwa aspek kognitif telah mencapai ketuntasan, dimana target ketuntasan sebesar $70 \%$ siswa yang memperoleh nilai diatas KKM dan hasil prestasi siswa aspek kognitif sebesar $75 \%$.Sehingga penelitian berakhir pada siklus II.

\section{Perbandingan Tindakan Antar Siklus}

Prestasi belajar siswa mengalami peningkatan dari siklus I ke siklus II.Pada siklus II aspek yang dinilai lagi hanya aspek kognitif.Peningkatan hasil belajar siswa dapat dilihat pada Gambar 1.

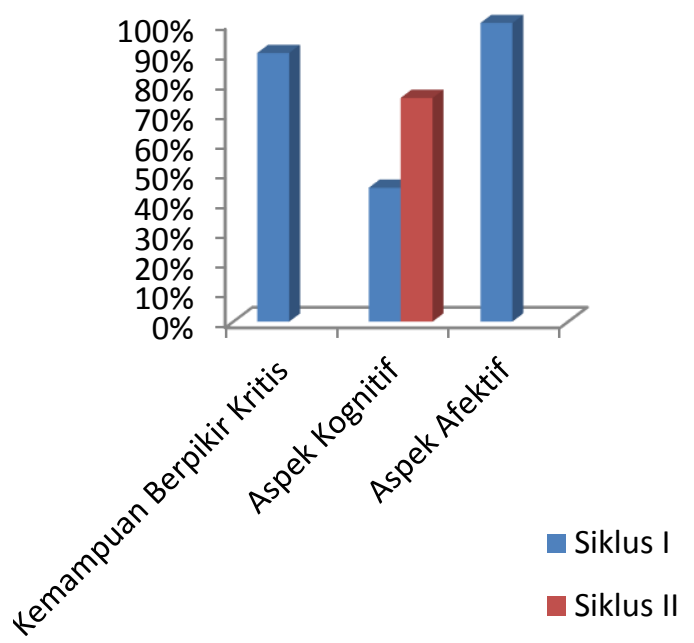

Gambar 1. Perbandingan Hasil Antar Siklus
Gambar 1 menunjukkan peningkatan dari siklus I ke siklus II pada aspek kognitif yang belum tercapai.Hal ini menunjukkan bahwa penggunaan model pembelajaran problem solving dilengkapi smartcard mampu meningkatkan kemampuan berpikir kritis dan prestasi belajar siswa pada materi kelarutan dan hasil kali kelarutan kelas XI IPA SMA Islam 1 Surakarta.

\section{KESIMPULAN}

Berdasarkan hasil penelitian yang telah dilakukan, maka dapat diambil kesimpulan bahwa (1) model pembelajaran Problem Solving dilengkapi Smart Card dapat digunakan untuk meningkatkan kemampuan berpikir kritis siswa pada materi Kelarutan dan Hasil Kali Kelarutan kelas XI IPA SMA Islam 1 Surakarta Tahun Ajaran 2016/2017. (2) model pembelajaran Problem Solving dilengkapi Smart Carddapat digunakan untuk meningkatkan prestasi belajar siswa pada materi Kelarutan dan Hasil Kali Kelarutan kelas XI IPA SMA Islam 1 Surakarta Tahun Ajaran 2016/2017.

\section{UCAPAN TERIMAKASIH}

Penelitian ini tidak dapat berjalan lancar tanpa dukungan dari berbagai pihak, untuk itu penulis mengucapkan terimakasih kepada Drs. Sudadi Wahyono selaku kepala sekolah SMA Islam 1 Surakarta yang telah memberikan izin untuk melakukan penelitian di sekolah tersebut. Terimakasih juga penulis ucapkan kepada Dwidjajanti S.Pd selaku guru mata pelajaran kimia yang telah ikut serta dalam pelaksanaan penelitian dan memberikan ijin peneliti untuk melakukan penelitian di dikelas XI IPA.

\section{DAFTAR RUJUKAN}

[1] Mulyasa, E. (2008). Standar Kompetensi dan Sertifikasi Guru. Bandung: PT. Remaja Rosdakarya. 
[2] Puangtong, Petchtone, Chaijaroen, \& Sumalee. (2014). The validation of web based learning environment model to enhance cognitive skills and critical thinkingfor undergraduate students. Procedia - Social and Behavioral Sciences, 669-673.

[3] Majid, A. (2013). Strategi Pembelajaran. Bandung: PT. Remaja Rosdakarya.

[4] Sudjana, N. (1996). Cara Belajar Siswa Aktif. Bandung: Sinar Baru Algensido.

[5] Shoimin, Aris. (2014). 68 Model Pembelajaran Inovatif dalam Kurikulum 2013. Yogyakarta: ArRuzz Media

[6] Turkay, S., Adinolf, S., Tirthali, D. (2012). Collectible Card Games as Learning Tools.Social and Behavioral Sciences, No. 463701 3705.

[7] Hasanah, U., Martini, K.S., \& Saputro, A.N.C. (2015). Penerapan Metode Problem Solving Terbimbing Untuk Meningkatkan Aktivitas dan Prestasi Belajar Kimia pada Materi Pokok Kelarutan dan Hasil Kali Kelarutan Siswa Kelas XI IPA 4 SMA Al Islam 1 Surakarta Tahun Pelajaran 2013/2014. JPK, vol.4 No.1 68-73.
[8] Kusumah \& Dwitagama. (2012). Mengenal Penelitian Tindakan Kelas. Jakarta: PT Indeks.

[9] Miles, M.B., \& Huberman, A.M. (2007). Analisis Data Kualitatif, Buku Sumber Tentang MetodeMetode Baru. Jakarta: Universitas Indonesia Press.

[10] Wiriatmadja. (2009). Metode Penelitian Tindakan Kelas. Bandung: Remaja Rosdakarya.

[11] Sugiyono. (2010). Metode Penelitian Kuantitatif, Kualitatif, dan $R \& D$. Bandung: Alfabeta

[12] Sunarya, dkk. (2001). Pengembangan Model Pembelajaran Kimia untuk Meningkatkan Ketrampilan Berpikir Kritis dan Ketrampilan Proses Sains Siswa SMU.Jurnal Pengajaran MIPA, vol. 2 No.2.

[13] Azwar, S. (2007). Sikap Manusia Teori dan Pengukurannya, edisi 2. Yogyakarta: Pustaka Pelajar. 